\title{
NUTRITIONAL EVALUATION OF MORINGA OLEIFERA LEAVES AS-UNCONVENTIONAL FEED STUFF IN THE DIETS OF NILE TILAPIA (OREOCHROMIS NILOTICUS) FINGERLINGES
}

\author{
Magouz' ${ }^{1}$ F. I.; Eweedah ${ }^{1}$.N. M; Khalafalla ${ }^{2}$. M. M and Seham \\ A. Abouzeid ${ }^{1}$ \\ ${ }^{1}$ Department of Animal Production, Faculty of Agriculture, \\ KafrelsheikhUniversity, Egypt. ${ }^{2}$ Department of Aquaculture, Faculty of \\ Aquatic and Fisheries Sciences, Kafrelsheikh University, Egypt
}

\begin{abstract}
This work was carried out in Fish Research laboratory, Department of Animal Production, Faculty of Agriculture, Kafr ElShiekh University. The feeding experiments dated from September until December 2014, for 12 weeks to study the effect of using different levels $(0,6,12,18,24 \%)$ of Moringa Oleifera Leaves (MOL) on growth performance, efficiency of feed utilization and chemical composition of Nile tilapia (0. niloticus) fingerlings. A total of 300 fish with $(10.66 \mathrm{~g})$ average initial body weight, were randomly allocated into 15 aquaria (20 fish in each).Fish in all treatments were daily fed the experimental diets at a level of $2 \%$ of the fish biomass. Experimental diet was given at two times daily, six days a week for 12 weeks. Diet contained $12 \% \mathrm{MOL}$ was significantly higher $(\mathrm{P}>0.05)$ in all the growth performance parameters as compared with the other treatments. Carcass composition affected with MOL substitution level The group fed control diet and $12 \% \mathrm{MOL}$ recorded the highest values and those fed the diet containing 18 and $24 \% \mathrm{MOL}$ recorded the lowest values.
\end{abstract}

Keywords: Nile Tilapia, Moringa Oleifera,Growth performance ,feed utilization and chemical composition .

\section{INTRODUCTION}

Nile tilapia (O.niloticus) was one of the first fish species cultured. Illustrations from Egyptian tombs suggested that Nile tilapia were cultured more than 3,000 years ago. Nile tilapia is still the most widely cultured species of tilapia in Africa (FAO,1997) World food fish aquaculture production expanded at an average annual rate of 6.2 percent in the period from 2000 until 2012 (9.5 percent in 1990-2000) from 32.4 million to 66.6 million tones. In the same period, growth was relatively faster in Africa (11.7\%) (FAO, 2014).

Moringa oleifera belongs to the moringaceae family and its origin is the north-west region of India, south of the Himalayan Mountains 
(Makkar and Becker, 1997). Now, it's widely cultivated and has become naturalized in many locations in the tropics (Fahey etal., 2001). There are thirteen species of Moringa trees in the family moringaceae and that Moringa oleifera is the most widely cultivated species (Kristin, 2000).

Moringa grows in all types of soils; Moringa is a drought tolerant plant that can be grown in diverse soils, except those that are water logged. Slightly alkaline clay and sandy loam soils are considered the best media for this species due to their good drainage (Ramchandran et al., 1980 and Abdul, 2007).

Recently, Moringa has been described as miracle tree. All parts of the Moringa tree are edible and have long been consumed by humans. It has in numerous uses; among the many attributes of this remarkable tree are used in many countries for purification of turbid water. The seed oil is edible, and the remaining meal can be used as a protein meal in livestock diet. The leaves of this tree are also edible and are highly nutritious.

The aim of the present study is to evaluate the using of different levels $(0,6,12,18$, and $24 \%)$ of Moringa Oleifera leaves , as a dietary protein source for Nile tilapia and its effect on growth performance, efficiency of feed utilization and body composition and hepato somatic index .

\section{1-Experimental fish:}

\section{MATERIALS AND METHODS}

The experimental fishes were collected from a private tilapia hatchery located in El-zawya area in Kafr El-Sheikh Governorate. The fishes were transported in plastic pages filled with water and oxygen to the wet lab in Kafr El Sheikh Faculty of Agriculture.

All fishes were kept two weeks in a fiber glass tank before their distribution in the experimental aquaria for the adaptation on the new environment. The fishes were randomly divided into equal groups in the experimental aquaria ( 20 fish /aquarium).

\section{2-Experimental design of rearing fish:}

A group of 300 Nile Tilapia fingerling (O. niloticus ) fish with an average initial body weight(10.66 gm ) were randomly allotted in to 5 treatments in 15 glass aquaria $(80 \times 35 \times 40 \mathrm{~cm})$. Fish were stocked at a rate of 20 fish in each aquarium Each treatment was applied in three aquaria.Fish were graded and divided in to four similar groups fed dietary protein ranged between $31.11 \%$ to $31.67 \%$. Each aquarium was supplied with compressed air through air pump for oxygen requirement .Fresh tap water was used for replacing about one third of the total water volume in each aquarium daily after the removal of fecal wastes daily by siphoning .Water temperature was controlled thermostatically and measured two times daily using a thermometer . 


\section{3-Experimental diets and feeding regime:}

Two weeks before the starting of the experimental trial about to weeks the fishes were adapted to a basal experimental diet containing $30 \%$ crude protein and consisted of fish meal, soybean meal, yellow corn and wheat bran, Ca phosphate, sunflower oil and Vit.\&Min. mixture. Five experimental commercial diets were formulated to contain Moringa Oleifera leaves (MOL) at five levels $(0,6,12,18$ and $24 \%$ ) by replacing soybean, yellow corn, wheat bran and rice bran (Table 1). Each diet was fed to three randomly assigned aquaria.

The ingredients of the experimental diets were ground in a hammer mill and mixed well together for homogeneity. Thereafter, the water $(25 \%)$ was added to the mixture which was allowed to pass through a mincing machine to produce $2.5 \mathrm{~mm}$ pellets in diameter according to shimeino et al.,(1993). The wet pellets were dried in an oven at $60^{\circ} \mathrm{C}$ for 24 hours .the diets collected, tagged and stored.

Table (1): Ingredients and Composition of the experimental diets

\begin{tabular}{|c|c|c|c|c|c|}
\hline Ingredients\% & $\mathbf{T}_{\mathbf{1}}$ & $\mathbf{T}_{\mathbf{2}}$ & $\mathbf{T 3}$ & $\mathbf{T 4}$ & T5 \\
\hline \hline Fish meal & 11 & 11 & 11 & 11 & 11 \\
\hline Soybean meal & 43 & 40.5 & 38 & 35 & 32 \\
\hline Yellow corn & 28 & 28 & 28 & 22 & 20 \\
\hline Wheat bran & 7 & 3.5 & - & 5 & 3 \\
\hline Rice bran & 6 & 6 & 6 & 4 & 5 \\
\hline Sunflower oil & 3 & 3 & 3 & 3 & 3 \\
\hline Di -Ca phosphate & 1 & 1 & 1 & 1 & 1 \\
\hline Vit.\&Min. mixture $^{*}$ & 1 & 1 & 1 & 1 & 1 \\
\hline Moringa Oleifera & 0 & 6 & 12 & 18 & 24 \\
\hline
\end{tabular}

*Vitamins and minerals premix (product of Victoir) each $3 \mathrm{~kg}$ contain: 12.00 .000 IU Vit. A ; 3.00.000 IU Vit. D3; 700 mg Vit. E; 500 mg Vit. K3; 500 mg Vit. B1; 200 mg Vit. B2; 600 mg Vit. B6; $3000 \mu \mathrm{g}$ Vit. B12; 450 mg Vit. C; $3000 \mu \mathrm{g}$ Niacin; 3000 mg Methionine; 10000 mg Choline Chloride; $600 \mu \mathrm{g}$ Biotin; $300 \mathrm{mg}$ Folic acid; $670 \mathrm{mg}$ Pantothenic acid; $3000 \mathrm{mg}$ Magnesium Sulphate; 1800 mg Zinc Sulphate; 10000 mg Iron Sulphate; 3000 mg Copper Sulphate; 300 mg Cobalt Sulphate.

Fish in all treatments were fed daily on the experimental diets at a level of $2 \%$ of the fish biomass. The feed was offered twice daily at 9.0 a.m and 2.0 p.m.The fish groups were weighed weekly and the amount of the feed was adjusted according to the actual body weight changes.

\section{4-Analytical methods:}

\subsection{Measurements of water parameters:}

Water samples were taken weekly from each aquarium to determine water quality parameters such as the values of $\mathrm{pH}$, dissolved oxygen concentration and temperature. Light was adjusted by a timer to provide $14 \mathrm{~h}$ light and $10 \mathrm{~h}$ darkness. One third of water volume was changed daily and the whole water volume was totally changed every week. 
Water temperature was measured by using a thermometer (daily), water $\mathrm{pH}$ value was determined by using digital $\mathrm{pH}$ meter (Orient Research Model 201), dissolved oxygen concentration by using an oxygen meter (model 9070).

\section{2- Proximate analysis of the experimental diets and fish body:}

Determination of DM, CP, EE, CF and ash in the basal diet, experimental diets and in fish body at the start and the end of the experiment for different groups were carried out according to the methods described by A.OA.C. (1990).

At the end of the experiment, five fish were derived from each group for drying at $60^{\circ} \mathrm{C}$ for 48 hours and then milled through electrical mill and stored in deep freezer until analysis.

\section{5-Growth performance and efficiency of feed and protein utilization:}

The growth performance and feed utilization parameters were calculated according to the following equations:

- Total weight gain (TWG):

TWG $=$ final weight $(\mathrm{g})$ - initial weight $(\mathrm{g})$

- Average daily gain (ADG):

ADG $(\mathrm{g})=$ TWG $(\mathrm{g}) /$ Time (days)

- Survival rate (SR \%):

SR $\%=$ Total number of fish at the end of the experimental $\times 100 /$ total number of fish at the start of the experiment.

- Specific growth rate (SGR, \% / day):

$\mathrm{SGR}=100 \times[$ In wt $1-\operatorname{In} \mathrm{wt} 0 / \mathrm{T}]$

Whereas:

In: Natural log.

Wt1: Final weight $(g)$

$\mathrm{Wt0}$ : Initial weight $(\mathrm{g})$

$\mathrm{T}$ : Time in days

- Feed conversion ratio (FCR):

FCR = Total feed consumption (g) / Weight gain (g)

- Protein efficiency ratio (PER):

$\mathrm{PER}=$ Body weight gain $(\mathrm{g}) /$ protein intake $(\mathrm{g})$

6- Internal Organs indices:

Five fish were killed at the end of the experiment, and then abdominal cavity was opened to remove liver which was weighed individually. Hepato somatic index (HSI) was calculated as follow :

-HSI=Liver weight $\times 100$ / fish weight (Jangaard et al., 1967).

7- Statistical analysis:

The obtained numerical data were statistically analyzed using SPSS (2006) for one-way analysis of variance. When F-Test was significant ,least significant difference was calculated according to Duncan(1955). 


\section{RESULTS AND DISCUSSION \\ 1-Chemical composition of ingredients:}

Chemical composition of the different ingredients used in the experimental diets is shown in Table (2). Which include soybean meal, herring fish meal, wheat bran and yellow corn .Results in Table (2), The average chemical composition of Moringa oleifera leaves in this study was in agreement with those obtained by Makker and Becker, (1996).

Table (2): The chemical analysis of ingredients used in the experimental diets (On DM basis \%)

\begin{tabular}{|c|c|c|c|c|c|c|c|c|}
\hline Ingredients & DM & OM & CP & EE & CF & Ash & NFE & $\begin{array}{c}\text { GE}^{*} \\
\text { Kcal/100g }\end{array}$ \\
\hline Soybean meal & 91.80 & 92.15 & 44.50 & 6.23 & 5.90 & 7.85 & 35.52 & 460.20 \\
\hline fish meal & 92.2 & 89.5 & 71.97 & 14.65 & 0.90 & 10.50 & 1.98 & 553.43 \\
\hline Rice bran & 94.33 & 89.07 & 11.36 & 8.48 & 19.52 & 10.93 & 49.71 & 354.09 \\
\hline Wheat bran & 90.45 & 95.2 & 11.52 & 6.98 & 9.00 & 4.98 & 67.52 & 415.99 \\
\hline yellow corn & 89.10 & 97.5 & 8.85 & 7.45 & 1.90 & 2.50 & 79.3 & 455.05 \\
\hline Moringa leaves & 91.50 & 91.77 & 26.34 & 5.97 & 4.63 & 8.23 & 54.83 & 436.38 \\
\hline
\end{tabular}

*Gross energy was calculated according to NRC (1993) by using factors of 5.65, 9.45 and 4.22 Kcal per 100 gram of protein, lipid and carbohydrate, respectively.

\section{2-Chemical composition of the experimental diet:}

Chemical composition and calculated gross energy of different experimental diets are presented in Table (3). The experimental diets were isonitrogenous, and contained nearly similar DM, CP, EE, CF, Ash ,NFE and GE content and P/E ratio.

Table 3: Chemical Proximate analysis of the experimental diets

\begin{tabular}{|c|c|c|c|c|c|}
\hline Ingredients & $\begin{array}{c}\text { D1 } \\
\text { Control }\end{array}$ & D2 & D3 & D4 & D5 \\
\hline Dry matter & 93.08 & 92.19 & 92.79 & 90.97 & 92.93 \\
\hline Organic matter & 91.72 & 92.45 & 92.36 & 91.85 & 92.40 \\
\hline Crude protein & 31.35 & 31.34 & 31.11 & 31.29 & 31.67 \\
\hline Ether extract & 15.44 & 15.77 & 15.77 & 16.08 & 15.51 \\
\hline Crude fiber & 5.56 & 5.64 & 5.58 & 5.58 & 5.50 \\
\hline ASH & 7.79 & 8.20 & 7.79 & 8.73 & 8.34 \\
\hline Nitrogen free extract & 39.86 & 39.05 & 39.75 & 38.32 & 38.98 \\
\hline \multicolumn{6}{|c|}{ Calculated energy value: } \\
\hline${ }^{*} \mathrm{GE}$ (kcal/100g) & 491.25 & 490.89 & 492.55 & 490.46 & 490.00 \\
\hline **DE(kcal/100g) & 368.44 & 368.17 & 369.41 & 367.85 & 367.5 \\
\hline${ }^{\star \star \star} \mathrm{P} / \mathrm{E}(\mathrm{g} / \mathrm{kcal})$ & 63.81 & 63.84 & 63.16 & 63.79 & 64.63 \\
\hline
\end{tabular}

GE (gross energy) was calculated according to NRC (1993) by factors of 5.65, 9.45 and 4.22 kcal per gram of protein, Lipid and carbohydrate, respectively.

** DE (digestible energy) was calculated by applying the coefficient of 0.75 to convert gross energy to digestible energy.

${ }^{* * *} \mathrm{P} / \mathrm{E}$ (protein energy ratio) $=$ crude protein $\times 1000 /$ digestible energy. (Pantha 1982) 


\section{3-Water quality parameters:}

Water quality parameters of the experimental aquaria were insignificantly affected by different treatments during the experimental period (12 weeks). Average water analytical data are summarized in Table (4). In genera1, average water temperature of the different treatments was ranged between 26.03 and $27.23^{\circ} \mathrm{C}$. Averages of $\mathrm{pH}$ values were ranged from 7.73 to 7. 94. The concentration of dissolved oxygen $(\mathrm{mg} / \mathrm{L})$ was ranged between 4.49 and5.48 mg/L which are suitable for fish growth .Averages of Total ammonia values were ranged from 0.24 to 0.26 .Data indicated that the values obtained were acceptable ranges required for normal growth of tilapia. All values of the above-mentioned parameters were suitable for the normal growth and reproduction of tilapia for warm water fish (Tahoun, 2002 and 2007).

Table (4): Average of some physical and chemical parameters of water during the experimental period

\begin{tabular}{|c|c|c|c|c|c|}
\hline Diets no. & $\begin{array}{c}\text { Moringa } \\
\text { Oleifera } \\
\text { leaves } \%\end{array}$ & $\begin{array}{c}\text { Water } \\
\text { temperature }\end{array}$ & Water $\mathrm{pH}$ & DO $(\mathbf{m g} / \mathbf{L})$ & $\begin{array}{c}\text { Total ammonia } \\
(\mathbf{m g} / \mathbf{L})\end{array}$ \\
\hline $\begin{array}{c}\text { Control } \\
\text { T1 }\end{array}$ & 0 & $27.06 \pm 0.03$ & $7.94 \pm 0.04$ & $4.49 \pm 0.18$ & $0.26 \pm 0.02$ \\
\hline T2 & 6 & $26.16 \pm 0.03$ & $7.80 \pm 0.02$ & $5.05 \pm 0.19$ & $0.24 \pm 0.01$ \\
\hline T3 & 12 & $26.03 \pm 0.03$ & $7.86 \pm 0.01$ & $5.48 \pm 0.01$ & $0.26 \pm 0.02$ \\
\hline T4 & 18 & $27.23 \pm 0.03$ & $7.81 \pm 0.02$ & $5.43 \pm 0.04$ & $0.26 \pm 0.011$ \\
\hline T5 & 24 & $27.16 \pm 0.03$ & $7.73 \pm 0.04$ & $5.30 \pm 0.05$ & $0.26 \pm 0.02$ \\
\hline
\end{tabular}

\section{4- Feed intake and nutrient utilization:}

There were no significant differences $(P>0.05)$ in feed intake among fish fed T1(control) and T3 contained 0 and $12 \% \mathrm{MOL}$ (table 5 ). They recorded a higher feed intake values than that diets containing 6 and $18 \%$, but there were significant differences $(P<0.05)$ in feed intake between these two diets and the other treatments, while T5 contained $24 \% \mathrm{MOL}$ recorded lower feed intake values as compared with the other treatments. Feed conversion ratio (FCR) and protein efficiency ratio (PER) are also illustrated in (Table 5). Data showed that the FCR were not significantly different among fish fed $\mathrm{T} 1$ (control) and T3 contained 0 and 12\% Moringa Oleifera. On the other hand, the differences between the T4 and T5 contained 18 and $24 \%$ MOL were not significantly different, T5 recorded the highest FCR value as compared with the other treatments.

Richter et al.,(2002) showed that the feed intake ( FI ), (FCR) and protein efficiency ratio ( $P E R$ ) were found to be similar in diets 0 and $10 \% \mathrm{MOL}$ and those values were significantly higher than those of fish 
fed diet containing 20 and $30 \%$ moringa leaves as compared with the control diet.

Table (5): Average of feed intake, feed conversion ratio, protein efficiency ratio (\%) of Nile tilapia fed different experimental diets:

\begin{tabular}{|c|c|c|c|c|}
\hline Diets no. & $\begin{array}{c}\text { Moringa } \\
\text { Oleifera leave } \\
\%\end{array}$ & $\begin{array}{c}\text { Feed intake } \\
\text { g/fish }\end{array}$ & FCR & PER \\
\hline T1 Control & - & $25.88 \pm 0.42 \mathrm{a}$ & $1.51 \pm 0.133 \mathrm{a}$ & $2.06 . \pm 0.021 \mathrm{a}$ \\
\hline T2 & 6 & $23.78 \pm 0.59 \mathrm{~b}$ & $1.62 \pm 0.068 \mathrm{a} \mathrm{b}$ & $1.94 \pm 0.069 \mathrm{~b}$ \\
\hline T3 & 12 & $25.79 \pm 0.36 \mathrm{a}$ & $1.56 \pm 0.0437 \mathrm{a}$ & $2.08 \pm 0.056 \mathrm{a}$ \\
\hline T4 & 18 & $23.73 \pm 1.55 \mathrm{~b}$ & $2.33 \pm 0.0592 \mathrm{c}$ & $1.37 \pm 0.027 \mathrm{c}$ \\
\hline T5 & 24 & $21.83 \pm 0.33 \mathrm{c}$ & $2.08 \pm 0.0519 \mathrm{c}$ & $1.48 \pm 0.028 \mathrm{c}$ \\
\hline
\end{tabular}

$\mathrm{A}, \mathrm{b}$ and $\mathrm{c}$ mean the column bearing different letters differ significantly at 0.05 level.

control T1 ( diet 1 without MOL), T2 (diet MOL replace 6\% ),T3 (diet 3 MOL replace 12\%) , T4 ( diet 4 replace $18 \%$ ) and T5 (diet 5 replace $24 \%$ )

\section{5-Growth performance and survival rate:}

Data concerning growth responses of Nile tilapia fingerlings presented as initial and final weight, average weight gain, average daily gain, specific growth rate and survival rate are shown in Table (6). The fish fed diets containing 0 and $12 \% \mathrm{MOL}$ recorded the highest values for all growth parameters .However Richter et al.,(2002)found a significant $(P<0.05)$ reduction in final body weight (FBW )and body weight gain( BWG) in fish groups fed 20 and $30 \%$ $\mathrm{MOL}$ as compared with fish fed the control diet, but there were no significant differences between $10 \% \mathrm{MOL}$ and the control diets. However, mortality related feeding was observed during seven weeks feeding period. The diets with higher inclusion levels of Moringa leaves significantly depressed growth performance of $O$. niloticus. These results suggested that Moringa leaf meal can be used to substitute up to $10 \%$ of dietary protein in Nile tilapia without a significant reduction in growth. Preliminary trial with Moringa leaf meal was used in Tilapia niloticus feeds indicated growth reducing effects at the high inclusion level of inclusion of raw leaf meal.

In Nile tilapia ,final weights, average weight gain, average daily gain, specific growth rate significantly $(P<0.05)$ decreased with increasing MOL levels in the diets except fish fed on the level of $12 \% \mathrm{MOL}$. Dongamieza et al ., (2006) explained the poor growth of Tilapia in high moringa diet by the higher selectively of tilapia to the anti metabolic factors, probably through partial inhibition of digestive enzymes and complexation of dietary protein . 
Table (6): Growth performance parameters of Nile tilapia fed different the experimental diets

\begin{tabular}{|c|l|l|l|l|l|l|}
\hline $\begin{array}{l}\text { Treatmen } \\
\mathbf{t}\end{array}$ & \multicolumn{1}{|c|}{$\begin{array}{l}\text { Initial } \\
\text { BW(g) }\end{array}$} & \multicolumn{1}{|c|}{$\begin{array}{c}\text { Final } \\
\text { BW }(\mathrm{g})\end{array}$} & \multicolumn{1}{|c|}{$\begin{array}{c}\text { AWG } \\
(\mathrm{g})\end{array}$} & \multicolumn{1}{|c|}{$\begin{array}{c}\text { ADG } \\
(\mathrm{g})\end{array}$} & \multicolumn{1}{c|}{ SGR(\%) } & SR (\%) \\
\hline $\begin{array}{l}\text { ControlT } \\
\mathbf{1}\end{array}$ & $\begin{array}{l}10.78 \pm 0.1 \\
6\end{array}$ & $\begin{array}{l}27.50 \pm 0.25 \\
\mathrm{a}\end{array}$ & $\begin{array}{l}16 . \\
72 \pm 0.66 \mathrm{a}\end{array}$ & $0.20 \pm 0.06 \mathrm{a}$ & $1.2 \pm 0.02 \mathrm{a}$ & $98.33 \pm 1.66$ \\
\hline T2 & $\begin{array}{l}10.55 \pm 0.1 \\
6\end{array}$ & $\begin{array}{l}25.03 \pm 0.78 \\
\mathrm{~b}\end{array}$ & $\begin{array}{l}14.48 \pm 0.81 \\
\mathrm{~b}\end{array}$ & $\begin{array}{l}0.17 \pm 0.01 \mathrm{a} \\
\mathrm{b}\end{array}$ & $\begin{array}{l}1.02 \pm 0.02 \\
\mathrm{~b}\end{array}$ & $95.00 \pm 2.88$ \\
\hline T3 & $\begin{array}{l}10.59 \pm 0.1 \\
5\end{array}$ & $\begin{array}{l}27.28 \pm 1.04 \\
\mathrm{a}\end{array}$ & $\begin{array}{l}16.7 \pm 0.89 \mathrm{a} \\
0.20 \pm 0.01 \mathrm{a}\end{array}$ & $1.13 \pm 0.01 \mathrm{a}$ & $96.66 \pm 3.33$ \\
\hline T4 & $\begin{array}{l}10.63 \pm 0.0 \\
4\end{array}$ & $\begin{array}{l}20.83 \pm 0.46 \\
\mathrm{c}\end{array}$ & $\begin{array}{l}10.20 \pm 0.26 \\
\mathrm{c}\end{array}$ & $\begin{array}{l}0.12 \pm 0.01 \mathrm{c} \\
0.81 \pm 0.01 \mathrm{c}\end{array}$ & $93.30 \pm 6.66$ \\
\hline T5 & $10.78 \pm 0.0$ & $\begin{array}{l}20.98 \pm 0.25 \\
\mathrm{c}\end{array}$ & $\begin{array}{l}10.20 \\
\pm 0.25 \mathrm{c}\end{array}$ & $\begin{array}{l}0.12 \pm 0.03 \\
\mathrm{c}\end{array}$ & $0.79 \pm 0.01 \mathrm{c}$ & $96.90 \pm 1.66$ \\
\hline
\end{tabular}

Mean superscripted (in the same column) with different letter significantly ( $P>0.05)$ differ .

Growth trial used five isonitrogeous (30gm/100 gm) and isoenergetic (18 $\mathrm{kj} / \mathrm{gm})$ diets in which Moringa leaf meal (M LM ) provided $15,30,40$, and $60 \mathrm{gm} / 100$ of total dietary protein. Digestibility trial showed that MLM had high digestibility for protein $(89 \%)$ and energy $(76.8 \%)$. There were a significant decline $(\mathrm{P}<0.05)$ in feed intake, specific growth rate and an increase in feed conversion ratio .This was largely due to the saponins and other antinutritional factors which affected palatability (Madalla et al., 2008).

Afuang et al. ( 2003) reported that growth performance of Nile tilapia fed raw Moringa leaf or diets containing methanol extracts of the Moringa leaf meal were evaluated .Weight gain was reduced and lipid accretion decreased with increased inclusion of raw Moringa leaves. It was observed from the results of the present study and those reported in the literature by several workers that using moringa oleifera leaves at low levels around $10 \%$ from the diet did not reduce the growth parameters or feed utilization due to the availability of the vital compounds such as the essential amino acids, fatty acids, vitamin and minerals in moringa leaves, but the growth can be reduced at the higher level of moringa. This may be attributed to the higher fiber content or the presence of some antinational factors such as tannin ,oxalate ,trypin inhibitors, saponin and cyanide (Ogbe and John ., 2011)

\section{6-Internal organs indices:}

The effect of different levels of MOL on fish organs indices are shown in Table 7. It was indicated that there was no significant difference $(P>0.05)$ in hepato somatic index $(\mathrm{HSI})$ between the diets contained 6 and $12 \% \mathrm{MOL}$. Liver index was the lowest in the diet contained 18 and $24 \% \mathrm{MOL}$. The highest $(\mathrm{HSI})$ was found in the diets contained $0,6,12 \% \mathrm{MOL}$. Generally, from the above results, the MOL caused positive effects on the hepato-somatic index. 
Table (7): Organs indices of Nile tilapia fingerlings fed different levels of Moringa Oleifera leave

\begin{tabular}{|c|c|c|}
\hline Treatment & MOL $\%$ & HSI \\
\hline Control T1 & - & $3.49 \pm 0.78 \mathrm{c}$ \\
\hline T2 & 6 & $3.18 \pm 0.09 \mathrm{~b} \mathrm{c}$ \\
\hline T3 & 12 & $3.11 \pm 0.14 \mathrm{~b}$ \\
\hline T4 & 18 & $2.43 \pm 0.11 \mathrm{a}$ \\
\hline T5 & 24 & $2.45 \pm 0.07 \mathrm{a}$ \\
\hline
\end{tabular}

$\mathrm{A}, \mathrm{b}$ and $\mathrm{c}$ mean the column bearing different letters differ significantly at 0.05 level.

\section{7-Body composition and energy content of Nile tilapia:}

The proximate chemical analysis of the whole body of the tested tilapia fish is given in table (8). Dry matter (DM) content increased significantly with increasing the level of moringa oleifera as T5 compared with the other treatments . while, The highest CP was observed in the fish groups T1, T2, and T3and the lowest values were in groups T4 and T5. EE were significantly decreased with at the high level of moringa oleifera , The highest ash was observed in the fish groups T1and T5 and the lowest values were in groups T2,T3 and T4. The highest GE was observed in the fish groups T1 and the lowest values were in groups T2, T3 ,T4 and T5.

Table 8: Proximate Chemical analysis and energetic value of the whole tilapia body as affected by the experimental diets .

\begin{tabular}{|c|c|c|c|c|c|}
\hline \multirow[t]{2}{*}{ Treat. No } & \multicolumn{5}{|c|}{$\%$ On Dry matter basis } \\
\hline & DM\% & CP\% & EE\% & Ash\% & $\begin{array}{c}\mathrm{GE}^{\star \star} \\
(\mathrm{Kcal} / 100 \mathrm{~g})\end{array}$ \\
\hline \multicolumn{6}{|c|}{ At the start of the experiment } \\
\hline & $93.60 \pm 0.15 \mathrm{c}$ & $58.11 \pm .501 \mathrm{c}$ & $13.53 \pm 0.217 c$ & $21.90 \pm 0.48 a$ & $654.09 \pm 1.9 a$ \\
\hline \multicolumn{6}{|c|}{ At the end of the experiment } \\
\hline T1 & $94.51 \pm 0.11 a b$ & $68.34 \pm 0.57 a$ & $23.30 \pm 1.10 a$ & $15.58 \pm 0.17 b$ & $639.17 \pm 9.70 \mathrm{a}$ \\
\hline T2 & $94.25 \pm 0.14 b$ & $67.70 \pm 0.66 a$ & $21.93 \pm 0.50 \mathrm{ab}$ & $14.21 \pm 0.52 \mathrm{c}$ & $\begin{array}{l}605.72 \pm \\
8.14 \mathrm{~b}\end{array}$ \\
\hline T3 & $95.10 \pm 0.39 a$ & $66.85+0.16 a b$ & $22.04 \pm 0.42 a b$ & $14.39 \pm 0.38 \mathrm{bc}$ & $\underset{c}{601.04 \pm 4.85 b}$ \\
\hline T4 & $94.80 \pm 0.29 a b$ & $66.17 \pm 0.39 b$ & $20.783 \pm 0.48 b$ & $13.69 \pm 0.16 \mathrm{c}$ & $577.48 \pm 8.68 \mathrm{c}$ \\
\hline T5 & $94.45 \pm 0.35 b$ & $65.45 \pm 1.24 b$ & $20.59 \pm 0.31 b$ & $15.74 \pm 0.23 b$ & $572.66 \pm 11.0 \mathrm{~d}$ \\
\hline
\end{tabular}

** Gross energy was calculated according to NRC (1993) by using factors of 5.65, 9.45 and 4.22 Kcal per 100 gram of protein, lipid and carbohydrate, respectively. 
Similar results were reported by Ali et al. (2015) who investigated the effect of dietary supplementation with $\operatorname{MOL}(0,5,10$ and $15 \mathrm{gm} / 1 \mathrm{~kg}$ diet)on growth performance. Their results revealed that Moringa Oleifera leaves supplementation significantly enhanced the fish growth over the control group. Concerning survival rate there was no significant differences with increasing MOL percentage in the diet while , feed conversion ratio was improved with inclusion moringa at $5 \%$ level ,Body protein content was significantly increased with increasing Moringa Oleifera in the diet, while moisture and fat content were significantly decreased with increasing MOL percentage in the diets.

\section{CONCLUSIONS}

Form The obtained results in the present study, it could be concluded that inclusion of $12 \%$ of Moringa Oleifera leaves can be recommended as a partial feed substitution in the diet of Nile tilapia without any adverse effects on growth performance parameter, efficiency of feed utilization and body composition.

\section{REFERENCES}

Abdul, D. A. S. (2007). Economic Importance of Moringa oleifera in Tafa Local Government Area of Niger State. NDE Project. Federal Collage of Forestry Mechanization, Kaduna, Nigeria.

Afuang W., P. Siddhuraju, and Becker, K. (2003). Comparative nutritional evaluation of raw,methanol extracted residues and methanol extracts of moringa (Moringa oleifera Lam.) leaves on growth performance and feed utilisation in Nile tilapia (Oreochromis niloticus L.). Aquacultre Res;34:1147-59.

Ali, S.M.El-Nadi and Mohamed K. Khamies (2015)Effect of dietary supplementation with Moringa Oleifera leaves on growth performance parameters on Nile tilapia (Oreochromis niloticus) .Research Journal of Fisheries and Hydrobiology ;10:10-14

AOAC (1990). Association Official Methods of Analysis. Gaithersburg, MD, USA, 15th ed. Association of Official Analytical Chemists, Arlington, VA.

Duncan, M. B.(1955). Multiple range and multiple F-test. Biometrics, 11:1-42.

Dongmieza E., Siddhuraju P., Francis G., and K. Becker(2006). Effects of dehydrated methanol extracts of moringa (Moringa oleifera Lam.) leaves and three of its fractions on growth performance and feed nutrient assimilation in Nile tilapia (Oreochromis niloticus L.). Aquaculture ; 261:407-22.

Fahey, J. W.; T. A. Zakmann and P. Talalay (2001). The chemical diversity and distribution of glucosinolates and isothiocyanates among plants. Phytochemistry 56(1): 5-51.

FAO (Food and Agricultural Organization)(1997). Review of the world Aquaculture fisheries circular .No 886, 1. FAO, Rome 163 pp . 
FAO (Food and Agricultural Organization) (2014).Fishery statistics Aquaculture production.

Jangaard, P. M.; Ackman, R. G. and Spios, J. C. (1967). Seasonal studies of the fatty acids composition of cod liver flesh, roe and milt lipids. J. Fish. Res. Bd. Of Canada, 24: 613-627.

Kristin, D. (2000). The Moringa Tree. ECHO Technical Note. ECHO, Florida, USA. 12PP. http:// www. Echonet. Org / tropicalag / moringa3. htm.

Macdonald, P., Edwards, R.A. and Greenhalgh, J.F.D. (1973). Animal Nutrition, 2nd Ed., Longman, London.

Madalla, N. 2008. Novel diet ingredients for Nile tilapia, Oreochromis niloticus L. Doctoral dissertation. Institute of Aquaculture, University of Stirling, Scotland

Makkar, H. P. S. and K. Becker (1996). Nutritional value and antinutritional components of whole and ethanol extracted Moringa oleifera leaves. Animal Science and Technology. 63: 211228.

Makkar, H. P. S. and K. Becker (1997). Nutrients and antiquality factors in different morphological parts of the Moringa Oleifera tree. J. Agric. Sci., Camb. 128: 311-332.

N. R. C. National Research council. (1993). Nutrition requirements of warm water fishes and shellfishes National Research Council, National Academy of science, Press Washington, DC, USA

Ogbe,A. O. and John, P. A. (2011). Proximate study, mineral and antinutrient composition of Moringa Oleifera leaves harvested from lafia, Nigeria : Potential benefits in poultry nutrition and health. Jurnal of Microbiology, Biotechnology, 3(3): 296-308.

Pantha, B. (1982). The use of soybean in practical feeds for Tilapia niloticus. M. Sc. Thesis. Univ. of Stirling.

Ramachandran, C.; K. V. Peter and P. K. Gopalakrishnan (1980). Drumstick (Moringa oleifera): A multipurpose Indian vegetable. Econ Bot 34(3): 276-283

Richter, N., Siddhuraju, P. and Becker, K.( 2002). Evaluation of nutritional quality of Moringa (Moringa oleifera Lam.) leaves as alternative protein source for tilapia (Oreochromis niloticus L.). Aquaculture. 217, 599- 611.

Shimeino, S;T.MaSumoto and T.Hujita .(1993) .Alternative protein Sources for fish meal dietS of young yellowtail .Nippon SuiSan GakkaiShi,59:137- 143.

SPSS, (2006). Statistical package for the social sciences, Versions15, command syntax reference. No 2006 inc., Chicago, IL, USA.

Tahoun, A. M. A. (2002). Effects of some environmental factors on growth performance and feed utilization of some warm water fishes in earthen ponds and glass aquaria.M. Sc. Thesis, University of Tanta.

Tahoun, A. M. A. (2007). Studies on some factors affecting the growth performance and feed utilization production and reproduction of 
Nile Tilapia.Ph.D. Dissertation. Fac.Of Agriculture,KafrEl-Sheikh University ,Egypt.

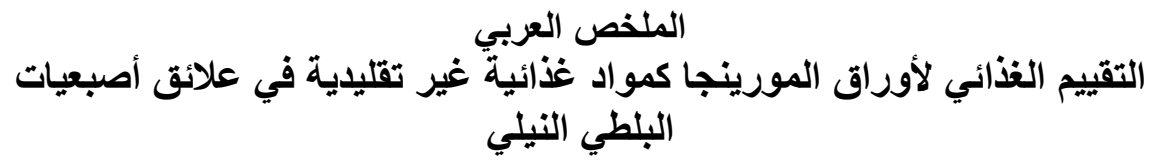

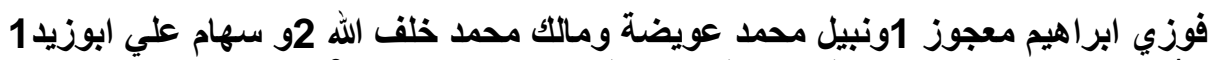

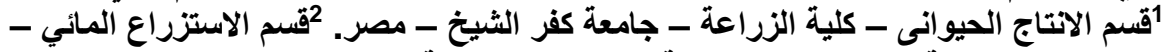

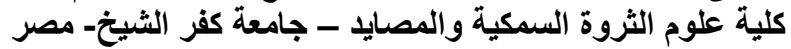

أجريت هذه الدراسه بمعمل بحوث الاسمالك, قسم الانتاج الحيو اني, كلية الزراعه,

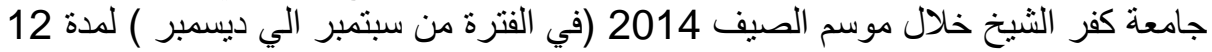

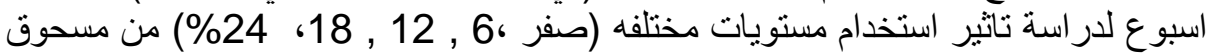

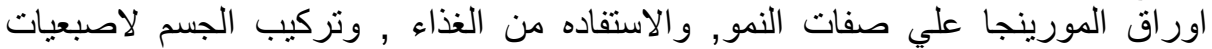
البلطي النيلي.استخدم في هذه الدر اسه 300 سمكة بمتوسط وزن الدئ إندائي

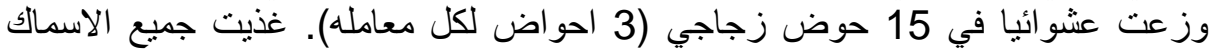

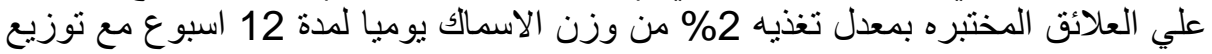

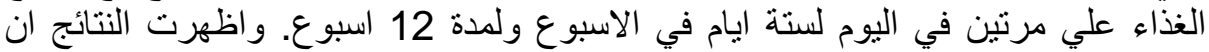

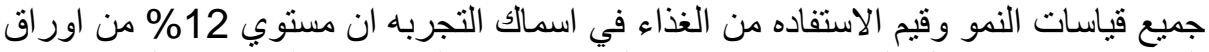

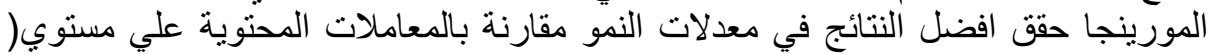

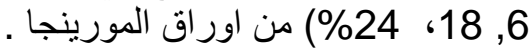

